\title{
Tissue Iodoprotein Formation during the Peripheral Metabolism of the Thyroid Hormones
}

\author{
Martin I. Surks, Harold L. Schwartz, and Jack H. Oppenheimer \\ From the Endocrine Research Laboratory, Medical Division, Montefiore \\ Hospital and Medical Center and the Department of Medicine, Albert \\ Einstein College of Medicine, Bronx, New York 10467
}

A в S T R A C T The formation of tissue iodoproteins during the peripheral metabolism of the thyroid hormones was examined by determining the concentration of nonethanol-extractable ${ }^{125} \mathrm{I}\left(\mathrm{NE}^{125} \mathrm{I}\right)$ in various tissues after the intravenous injection of $3,5,3^{\prime}$-triiodo-L-thyronine $\left(\mathrm{T} 3-{ }^{125} \mathrm{I}\right)$ and $\mathrm{L}$-thyroxine- ${ }^{-125} \mathrm{I}\left(\mathrm{T} 4-{ }^{125} \mathrm{I}\right)$ in groups of rats with iodide-blocked thyroid glands. 3 days after $\mathrm{T} 3{ }^{-20} \mathrm{I}$ and 7 days after $T 4{ }^{225} \mathrm{I}$ injection the concentration of $\mathrm{NE}^{125} \mathrm{I}$ in the liver and kidney was 5-10 times greater than in plasma. Smaller but nonetheless significant concentrations of $\mathrm{NE}^{125} \mathrm{I}$ were demonstrated in skeletal and cardiac muscle. Hepatic subcellular fractionation studies revealed that the major portion of the liver $\mathrm{NE}^{125} \mathrm{I}$ was in the microsomal fraction. Lower concentrations of $\mathrm{NE}^{125} \mathrm{I}$ were present in the nuclear, mitochondrial, and soluble fractions. When similar studies were performed in groups of rats pretreated with phenobarbital, an increase in the metabolic clearance of T3- ${ }^{128} \mathrm{I}(30 \%)$ and T4- ${ }^{205} \mathrm{I}(100 \%)$ was observed along with a highly significant increase in the $\mathrm{NE}^{125} \mathrm{I}$ concentration of the liver and plasma. The increase in hepatic $\mathrm{NE}^{125} \mathrm{I}$ in these studies was primarily due to the microsomal component.

Incubation of hepatic microsomes with T3 $3{ }^{205} \mathrm{I}$ and T4${ }^{125}$ I showed that NEI formation as well as deiodination appeared to obey simple Michaelis-Menten kinetics. Moreover, the maximal rate of both deiodination and NEI formation was increased when microsomes harvested from phenobarbital-treated rats were employed.

These studies indicate that thyroid hormone metabolism results in the formation of structural and soluble tissue iodoproteins in addition to circulating iodoproteins. The rate of formation of these moieties in the liver and plasma appears to be related to the rate of hormone metabolism.

Dr. Oppenheimer is a Career Scientist of the Health Research Council of New York City (I-222).

Received for publication 17 March 1969 and in revised form 13 June 1969.

\section{INTRODUCTION}

Recent studies from this laboratory have demonstrated that after injection of 3,5,3'-triiodo-L-thyronine- ${ }^{-25} \mathrm{I}$ (T3${ }^{125} \mathrm{I}$ ) and $\mathrm{L}$-thyroxine- ${ }^{128} \mathrm{I}$ (T4- ${ }^{125} \mathrm{I}$ ) into human beings and rats, a small but significant portion of the hormonal iodine appears in the plasma in a form which is nonextractable $\left(\mathrm{NE}^{125} \mathrm{I}\right)$ in acid butanol (1). Based on its physicochemical characteristics and its behavior in electrophoretic and chromatographic systems, plasma $\mathrm{NE}^{125} \mathrm{I}$ was identified as iodoprotein. Insignificant amounts of circulating iodoprotein were observed after injection of iodide- ${ }^{125} \mathrm{I}$ or monoiodotyrosine $-{ }^{125} \mathrm{I}\left(\mathrm{M}^{125} \mathrm{IT}\right)$. Studies performed in thyroidectomized rats indicated that the plasma iodoproteins originated during the peripheral metabolism of the thyroid hormones and not from thyroidal secretion. In separate studies Brown-Grant (2) has postulated that plasma iodoprotein formation might occur during triiodothyronine metabolism in guinea pigs. His suggestion was based on a decreasing plasma disappearance rate for injected $\mathrm{T} 3{ }^{-181} \mathrm{I}$ with a relative in. crease with time in plasma trichloroacetic acid-precipitable radioactivity.

The transfer of hormonal iodine to circulating proteins during hormonal metabolism raised the possibility that structural and soluble tissue proteins might be iodinated also. Although iodoprotein formation during thyroid hormone metabolism by various tissues in vitro has been frequently reported (3-12), the results of some of these studies must be queried since the incubation systems which were employed were supplemented with flavin mononucleotide (FMN). This cofactor in the presence of light has been shown to produce deiodination of iodothyronines and radioactivity remaining at the origin of chromatograms in the absence of any tissue components $(13,14)$. Moreover, the addition of a variety of proteins which have no deiodinating capability alone greatly accelerates this FMN effect (15). In several reports, however, in vitro iodoprotein formation was 
clearly demonstrated in incubation systems which did not require FMN $(8,9-12)$.

Fewer data are available on in vivo iodoprotein formation during thyroid hormone metabolism. In a study of the tissue localization of $\mathrm{T} 4-^{131} \mathrm{I}$ and $\mathrm{T} 3{ }^{121} \mathrm{I}$ in guinea pigs, Ford, Corey, and Gross (16) prepared radiochromatograms from tissue homogenates obtained 2-3 hr after intravenous injection of the labeled hormones. These authors observed that a small percentage of the tissue total radioactivity remained at the origin in the chromatograms of several tissues and speculated that the origin radioactivity might be a protein or polypeptide. The formation of tissue iodoproteins during hormone metabolism has also been demonstrated by Nunez, Rappaport, Jaquemin, and Roche (17). More recent studies of Dratman, Kuhlenbeck, and Crutchfield (18) suggest that iodoproteins may result from hormone metabolism in the developing neuraxis of the newborn rat. In a preliminary study from this laboratory, analysis of liver and carcass homogenates from rats whose iodine pools had been equilibrated with ${ }^{125} \mathrm{I}$ administered by daily injections revealed that approximately $10 \%$ of the tissue organic radioiodine was $\mathrm{NE}^{125} \mathrm{I}$ (1).

Despite these studies, comparatively little attention has been paid to this pathway in the in vivo metabolism of the thyroid hormones. The current study was, therefore, initiated further to explore this problem. An analysis was made of tissue and hepatic subcellular distribution of $\mathrm{NE}^{125} \mathrm{I}$ after $\mathrm{T} 4$ and $\mathrm{T} 3$ metabolism in normal rats and in animals in which the rate of hepatic hormone metabolism was stimulated by the administration of phenobarbital (19). The data presented in this report demonstrate that structural and soluble tissue iodoprotein formation occurs as a normal consequence of thyroid hormone metabolism. Moreover, phenobarbital treatment results in an increase in hepatic microsomal and plasma $\mathrm{NE}^{185} \mathrm{I}$ concentrations. Since we have previously reported that phenobarbital treatment leads to an increase in the specific activity of iodothyronine deiodinase in the hepatic microsomal fraction (20), in vitro studies of $\mathrm{NE}^{125} \mathrm{I}$ formation during the metabolism of T4 and T3 by isolated hepatic microsomes were carried out also.

\section{METHODS}

Preparations of L-thyroxine- ${ }^{125} \mathrm{I} \quad\left(\mathrm{T} 4-^{-125} \mathrm{I}\right)$, L-thyroxine- ${ }^{191} \mathrm{I}$ (T4- $\left.{ }^{131} \mathrm{I}\right), 3,5,3^{\prime}$-triiodo-L-thyronine- ${ }^{-20} \mathrm{I}$ (T3- $\left.{ }^{225} \mathrm{I}\right)$, and $3,5,3^{\prime}-$ triiodo-L-thyronine-- ${ }^{181} \mathrm{I}$ (T3-1981) with specific activities ranging from 20 to $40 \mathrm{mc} / \mathrm{mg}$ were obtained from Abbott Laboratories, North Chicago, Ill. Carrier-free iodide- ${ }^{181}$ I was obtained from the same source. 3-monoiodotyrosine- ${ }^{-25} \mathrm{I}$ ( $\left.\mathrm{M}^{125} \mathrm{IT}\right)$, SA $50 \mathrm{mc} / \mathrm{mg}$, was prepared by the iodination of tyrosine by the procedure outlined by Greenwood, Hunter, and Glover (21). Radioactivity was measured in a two channel Autogamma Spectrometer (Packard Instruments Co., Series $314 \mathrm{E})$. When both ${ }^{195} \mathrm{I}$ and ${ }^{131} \mathrm{I}$ were present in the same sample, the counts appearing in the ${ }^{200} \mathrm{I}$ channel were appropriately corrected for the ${ }^{131} \mathrm{I}$. Sufficient counts were accumulated so that counting error did not exceed $1 \%$.

Male Sprague-Dawley rats weighing between 150 and $250 \mathrm{~g}$ were employed in all studies. They were maintained on Wayne Lab-Blox and were allowed water ad lib. The phenobarbital ( $\mathrm{PB}$ ) groups were prepared by daily intraperitoneal injections of $\mathrm{PB}, 100 \mathrm{mg} / \mathrm{kg}$ body weight, for 5 days preceding the injection of labeled thyroid hormones. Treatment with $\mathrm{PB}$ was continued throughout the entire course of the various metabolic studies. Control animals were injected with isotonic saline. All rats were also injected daily with $1 \mathrm{mg} \mathrm{NaI}$ starting from the day preceding the administration of labeled thyroid hormones and throughout each study in order to prevent thyroidal accumulation of radioiodine released from the radioactive hormones during metabolism.

The experimental procedures which were carried out for the studies of $\mathrm{T} 4-^{125} \mathrm{I}$ and $\mathrm{T} 3-^{125} \mathrm{I}$ metabolism were similar. An exact amount $(20-40 \mu \mathrm{c})$ of the ${ }^{125} \mathrm{I}$-labeled iodothyronine in $1 \%$ albumin was injected intravenously through the tail vein in groups of two to four control and PB-treated rats. Heparinized blood samples were obtained at various intervals by cutting the tail. $35 \mathrm{~min}$ before the termination of each experiment $0.15 \mu \mathrm{c}$ of the ${ }^{181} \mathrm{I}$-labeled iodothyronine under study was injected into the tail vein. The rats were killed by exsanguination through the abdominal aorta under light ether anesthesia 3 days after T3- ${ }^{205} \mathrm{I}$ injection and 7 days after T4- ${ }^{-25} \mathrm{I}$ injection. The liver, kidney, heart, and a portion of skeletal muscle from the lower extremity were rapidly excised, chilled in ice, and weighed. $1 \mathrm{~g}$ portions of the liver, kidney, and skeletal muscle were minced and homogenized at $5^{\circ} \mathrm{C}$ in $0.05 \mathrm{M}$ phosphate buffer, $\mathrm{pH}$ 5.8. The entire heart was processed similarly after the chambers were opened and small blood clots removed by gentle rinsing in ice-cold saline. The radioactivity in samples of plasma and these tissue homogenates was then determined before and after four extractions with four volumes of $95 \%$ ethanol.

An additional $2 \mathrm{~g}$ portion from each liver was homogenized at $5^{\circ} \mathrm{C}$ in $0.25 \mathrm{M}$ sucrose and subcellular fractions were prepared by differential centrifugation according to the method of Schneider and Hogeboom (22). The radioactivity of the nuclear, mitochondrial, microsomal, and supernatant fractions was determined before and after $95 \%$ ethanol extraction as described above.

The counting rates in each sample were related to those in exact dilutions of the injected doses of both the ${ }^{125} \mathrm{I}$ - and ${ }^{131}$ I-labeled iodothyronines which were counted concurrently in order to obviate corrections for isotopic physical decay. The degree of extraction of the ${ }^{131}$ I-labeled iodothyronine in each sample was used as a control for the extraction procedure. Thus, the actual per cent $\mathrm{NE}^{125} \mathrm{I}$ in any sample was considered equivalent to the difference between the observed per cent $\mathrm{NE}^{125} \mathrm{I}$ and the per cent $\mathrm{NE}^{131} \mathrm{I}$.

Metabolic clearance of the thyroid hormones was calculated as the product of the fractional disappearance rate of plasma radioactivity over the first $48 \mathrm{hr}$ of each study and the total distribution volume determined by " 0 " time extrapolation. In the $T 3-{ }^{125} \mathrm{I}$ turnover studies, however, a major portion of the plasma radioactivity within this time interval consists of iodide- ${ }^{125} \mathrm{I}$ and $\mathrm{NE}^{125} \mathrm{I}$. Additional plasma samples were, therefore, counted before and after precipitation with $10 \%$ cold trichloroacetic acid (TCA). The concentration of T3-125I was assumed to represent the difference between the TCAprecipitable radioactivity and the $\mathrm{NE}^{125} \mathrm{I}$.

Data were expressed as mean $\pm_{\text {SEM }}$ corrected to an ideal body weight of $200 \mathrm{~g}$. Three separate experiments were per- 


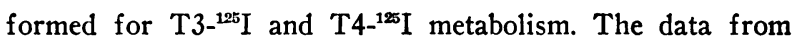
these studies were pooled and analyzed statistically using Student's $t$ test (23).

The occurrence of $\mathrm{NE}^{125} \mathrm{I}$ in skeletal and cardiac muscle was examined further in two additional experiments each using groups of three rats with iodide-blocked thyroid glands. Animals were killed as described above, 3 days after the intravenous injection of $40 \mu \mathrm{c}$ T3- ${ }^{125} \mathrm{I}$ and $17 \mathrm{hr}$ after the intravenous injection of $0.15 \mu \mathrm{c}$ albumin- ${ }^{181} \mathrm{I}$ (Abbott Laboratories). In one experiment (rat Nos. 787-789) excised skeletal and cardiac muscle was minced and counted before and after seven washes with $3 \mathrm{ml}$ human serum. The muscle minces were then homogenized in $0.05 \mathrm{M}$ phosphate buffer, $\mathrm{pH} 5.8$, and T3- ${ }^{131} \mathrm{I}(1000-2000 \mathrm{cpm})$ was added. The samples were recounted, extracted four times with four volumes of 95\% ethanol and again counted with appropriate standards of the injected dose. In another group of animals (rat Nos. 849-851), the excised skeletal and cardiac muscle was homogenized in $10 \mathrm{ml}$ phosphate buffer and centrifuged at $100,000 \mathrm{~g}$ for $60 \mathrm{~min}$ in a preparative ultracentrifuge (Arden Instruments, Inc., Rockville, Md.). The sedimented particles were suspended in $10 \mathrm{ml}$ of the same buffer and recentrifuged. The particulate fraction was then processed in the same manner as the muscle homogenates described above. In both of these experiments, the loss of albumin- ${ }^{131}$ I counts during the washing procedure or ultracentrifugation was assumed to reflect the degree of removal of plasma which had been trapped within the tissue sample. The degree of extraction of the added T3- ${ }^{181} \mathrm{I}$ served as a control of the extraction procedure.

The rate of formation of $\mathrm{NE}^{125} \mathrm{I}$ was studied in relation to the deiodination of $T 4{ }^{-125} \mathrm{I}$ and $\mathrm{T} 3{ }^{-125} \mathrm{I}$ by liver microsomes according to techniques previously described (20). Briefly, microsomes were harvested from groups of control and phenobarbital-treated rats by differential centrifugation and washed three times in $0.05 \mathrm{M}$ phosphate buffer, $\mathrm{pH}$ 5.8. Incubations were carried out in $2 \mathrm{ml}$ of the same buffer containing $4 \mathrm{mg}$ microsomal protein, tracer $\mathrm{T} 4-^{-{ }^{125} \mathrm{I}}$ or $\mathrm{T} 3-^{125} \mathrm{I}$, and various concentrations of nonradioactive $\mathrm{T} 4$ or $\mathrm{T} 3(0.25-$ $10.0 \mu \mathrm{g} / \mathrm{ml}$ ). After $10 \mathrm{~min}$ the reaction was terminated by the addition of $2 \mathrm{ml}$ of human serum. The per cent iodide was determined by rapid paper electrophoresis (24) and the per cent $\mathrm{NE}^{125} \mathrm{I}$ by counting a sample of the reaction mixture before and after four extractions with four volumes of $95 \%$ ethanol. Appropriate samples were processed in parallel to correct for the iodide- ${ }^{225} \mathrm{I}$ present in the radioactive preparations which were used and for variations in the extraction procedure. For studies of $\mathrm{M}^{125} \mathrm{IT}$ deiodination

\section{TABLE I}

Tissue NE ${ }^{125}$ I after T3-125I Metabolism in Control and Phenobarbital (PB-)Treated Rats*

\begin{tabular}{|c|c|c|c|c|c|c|}
\hline \multirow[b]{2}{*}{ Tissues } & \multicolumn{3}{|c|}{$\begin{array}{l}\text { Per cent of dose per } \mathrm{ml} \\
\text { or } \mathrm{g} \times 10^{4}\end{array}$} & \multicolumn{3}{|c|}{$\begin{array}{l}\text { Per cent of tissue } \\
\text { total }{ }^{125} I\end{array}$} \\
\hline & Control & PB-treated & $P<$ & Control & PB-treated & $P<$ \\
\hline Plasma & $7.5 \pm 0.5$ & $12.8 \pm 0.9$ & 0.001 & $25.4 \pm 1.6$ & $38.6 \pm 2.9$ & 0.001 \\
\hline Liver & $37.6 \pm 2.2$ & $52.5 \pm 3.2$ & 0.001 & $44.7 \pm 2.4$ & $57.7 \pm 3.1$ & 0.005 \\
\hline Kidney & $32.0 \pm 2.3$ & $30.3 \pm 1.9$ & NS & $37.4 \pm 2.7$ & $46.9 \pm 2.2$ & 0.02 \\
\hline Muscle & $2.2 \pm 0.3$ & $2.2 \pm 0.4$ & NS & $16.5 \pm 4.4$ & $18.5 \pm 2.2$ & NS \\
\hline Heart & $3.8 \pm 0.4$ & $3.6 \pm 0.7$ & NS & $23.8 \pm 3.5$ & $27.4 \pm 5.4$ & NS \\
\hline
\end{tabular}

* Data are corrected to an ideal body weight of $200 \mathrm{~g}$. The figures represent the mean ISEM for groups of 11 rats. Data are pooled from three separate experiments. $\mathrm{NS}=$ not significant $(P>0.05)$.

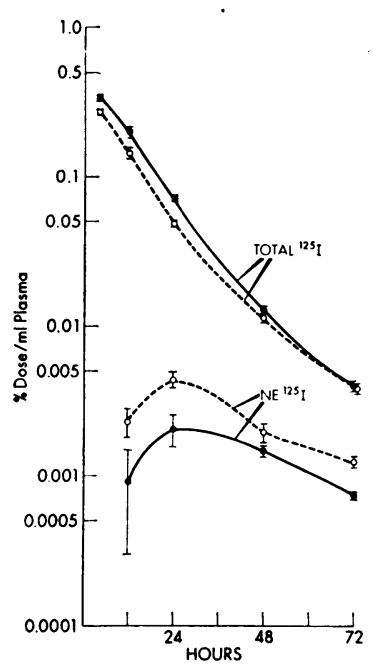

Figure 1 Plasma total ${ }^{125} \mathrm{I}$ and $\mathrm{NE}^{125} \mathrm{I}$ concentration after injection of $\mathrm{T} 3-{ }^{125} \mathrm{I}$ into groups of control ( $\left.-\bullet\right)$ and PB-treated (O--- $\mathrm{O}$ ) rats. All animals were injected daily with $1 \mathrm{mg} \mathrm{NaI}$. Data points represent the mean \pm SEM for groups of 11 rats and are pooled from three separate experiments.

and $\mathrm{NE}^{125} \mathrm{I}$ formation, microsomes were prepared as described by Stanbury (25). Incubations were carried out at $\mathrm{pH} 7.4$ with the addition of nicotinamide adenine dinucleotide phosphate, reduced form, $0.5 \mathrm{mg} / \mathrm{ml}$. Data were plotted according to Lineweaver and Burk (26). The maximal reaction rate, $V_{\max }$, was taken as the reciprocal of the $y$-intercept calculated by least squares analysis of at least five data points.

\section{RESULTS}

Tissue distribution of $N E^{125} I$. The concentrations of $\mathrm{NE}^{125} \mathrm{I}$ in the plasma and various tissues 3 days after the intravenous injection of $\mathrm{T} 3{ }^{120} \mathrm{I}$ are shown in Table $\mathrm{I}$. The highest concentrations of $\mathrm{NE}^{125} \mathrm{I}$ occurred in the liver and kidney. In the muscle and heart $\mathrm{NE}^{125} \mathrm{I}$ concentrations were appreciably less than in the plasma. Phenobarbital treatment induced a $30 \%$ increase in the metabolic clearance of $\mathrm{T} 3-{ }^{125} \mathrm{I}$ and was associated with a significant increase $(P<0.001)$ in the $\mathrm{NE}^{125} \mathrm{I}$ concentration in the liver and plasma. Hepatic NE ${ }^{125} I$ concentration rose from $37.6 \pm 2.2 \times 10^{-4}$ to $52.4 \pm 3.2 \times 10^{-4}$ per cent of the total dose per gram and the plasma $\mathrm{NE}^{125} \mathrm{I}$ increased from $7.5 \pm 0.5 \times 10^{-4}$ to $12.8 \pm 0.9 \times 10^{-4}$ per cent of the dose per milliliter. The increase in the hepatic and plasma $\mathrm{NE}^{125} \mathrm{I}$ concentration was due to an increase in both the tissue total ${ }^{125} \mathrm{I}$ and the per cent of the tissue total ${ }^{125} \mathrm{I}$ which was nonextractable. No significant changes in the $N E^{125} \mathrm{I}$ concentration were observed in kidney, muscle, and heart after phenobarbital treatment. Analysis of plasma samples obtained during these turnover studies revealed that the mean plasma $N E^{120} I$ concentration of the PB-treated group exceeded the mean $\mathrm{NE}^{125} \mathrm{I}$ concentration of the controls at all time intervals 
TABLE II

Tissue NE ${ }^{125}$ I after T4-125 I Metabolism in Control and Phenobarbital (PB)-Treated Rats*

\begin{tabular}{|c|c|c|c|c|c|c|}
\hline \multirow[b]{2}{*}{ Tissues } & \multicolumn{3}{|c|}{$\begin{array}{l}\text { Per cent of dose per } \mathrm{ml} \\
\text { or } \mathrm{g} \times 10^{4}\end{array}$} & \multicolumn{3}{|c|}{$\begin{array}{l}\text { Per cent of tissue } \\
\text { total } 125 \mathrm{I}\end{array}$} \\
\hline & Control & PB-treated & $P<$ & Control & PB-treated & $P<$ \\
\hline Plasma & $3.9 \pm 0.4$ & $5.7 \pm 0.6$ & 0.05 & $7.7 \pm 1.4$ & $22.6 \pm 5.0$ & 0.02 \\
\hline Liver & $61.3 \pm 8.3$ & $107.3 \pm 9.1$ & 0.01 & $58.3 \pm 1.5$ & $85.3 \pm 2.9$ & 0.001 \\
\hline Kidney & $24.1 \pm 1.6$ & $22.4 \pm 1.4$ & NS & $46.3 \pm 2.8$ & $60.1 \pm 3.7$ & 0.05 \\
\hline Muscle & $1.1 \pm 0.4$ & $0.4 \pm 0.6$ & NS & $8.4 \pm 1.1$ & $11.3 \pm 2.6$ & NS \\
\hline Heart & $2.1 \pm 0.2$ & $1.8 \pm 0.2$ & NS & $15.8 \pm 1.5$ & $22.5 \pm 3.8$ & NS \\
\hline
\end{tabular}

* Data are corrected to an ideal body weight of $200 \mathrm{~g}$. The figures represent the mean \pm SEM for eight control and six PB-treated rats. Data are pooled from three separate experiments. NS $=$ not significant $(P>0.05)$.

studied (Fig. 1) despite the fact that the plasma total ${ }^{120} \mathrm{I}$ was generally lower in the PB-treated group.

When tissue analyses were carried out 7 days after the intravenous injection of $\mathrm{T} 4-^{120} \mathrm{I}$ (Table II), the relative distribution of $\mathrm{NE}^{125} \mathrm{I}$ among the various tissues was comparable to that observed in the $\mathrm{T} 3-{ }^{125} \mathrm{I}$ studies. The highest $\mathrm{NE}^{125} \mathrm{I}$ concentration occurred in the liver and kidney. Phenobarbital treatment resulted in an increase in the mean metabolic clearance of $\mathrm{T} 4{ }^{125} \mathrm{I}$ from $36.7 \pm 2.2$ to $70.1 \pm 4.1 \mathrm{ml} /$ day per $200 \mathrm{~g}$ body weight $(P<0.001)$ and in the $\mathrm{NE}^{125} \mathrm{I}$ concentration of the plasma $(P<0.05)$ and liver $(P<0.01)$.

Special studies were performed to determine whether the low concentrations of $\mathrm{NE}^{125} \mathrm{I}$ observed in muscle and heart after the metabolism of $\mathrm{T} 3{ }^{205} \mathrm{I}$ and $\mathrm{T} 4-^{208} \mathrm{I}$ resulted from NEI formation within these tissues or from plasma $N^{125} \mathrm{I}$ trapped within the tissue sample. Muscle and heart minces were prepared from three rats (Nos. 787789) 3 days after T $3{ }^{125} \mathrm{I}$ and $17 \mathrm{hr}$ after albumin ${ }^{181} \mathrm{I}$ injection (Table III). Based on data from preliminary studies, albumin $-{ }^{131}$ I employed as a label for the plasma proteins (including plasma $\mathrm{NE}^{12} \mathrm{I}$ ) was considered to be completely distributed at this time interval. Extensive washing of these tissue minces removed an average of $94.4 \%$ of the albumin $-{ }^{131} \mathrm{I}$ from the muscle and $91.0 \%$ from the heart. After homogenization of the washed minces followed by extraction, an average of $33.4 \%$ and $31.5 \%$ of the washed tissue ${ }^{125} \mathrm{I}$ was nonextractable for the muscle and heart, respectively. Thus, an average of $8.5 \%$ of the muscle total ${ }^{125} \mathrm{I}$ and $12.7 \%$ of the heart total ${ }^{125} \mathrm{I}$ was $\mathrm{NE}^{125} \mathrm{I}$. The estimated contribution of the residual plasma $\mathrm{NE}^{125} \mathrm{I}$ to the tissue $\mathrm{NE}^{125} \mathrm{I}$ was then cal-

TABLE III

NE ${ }^{125} I$ in Muscle and Heart after T3-125 I Metabolism*

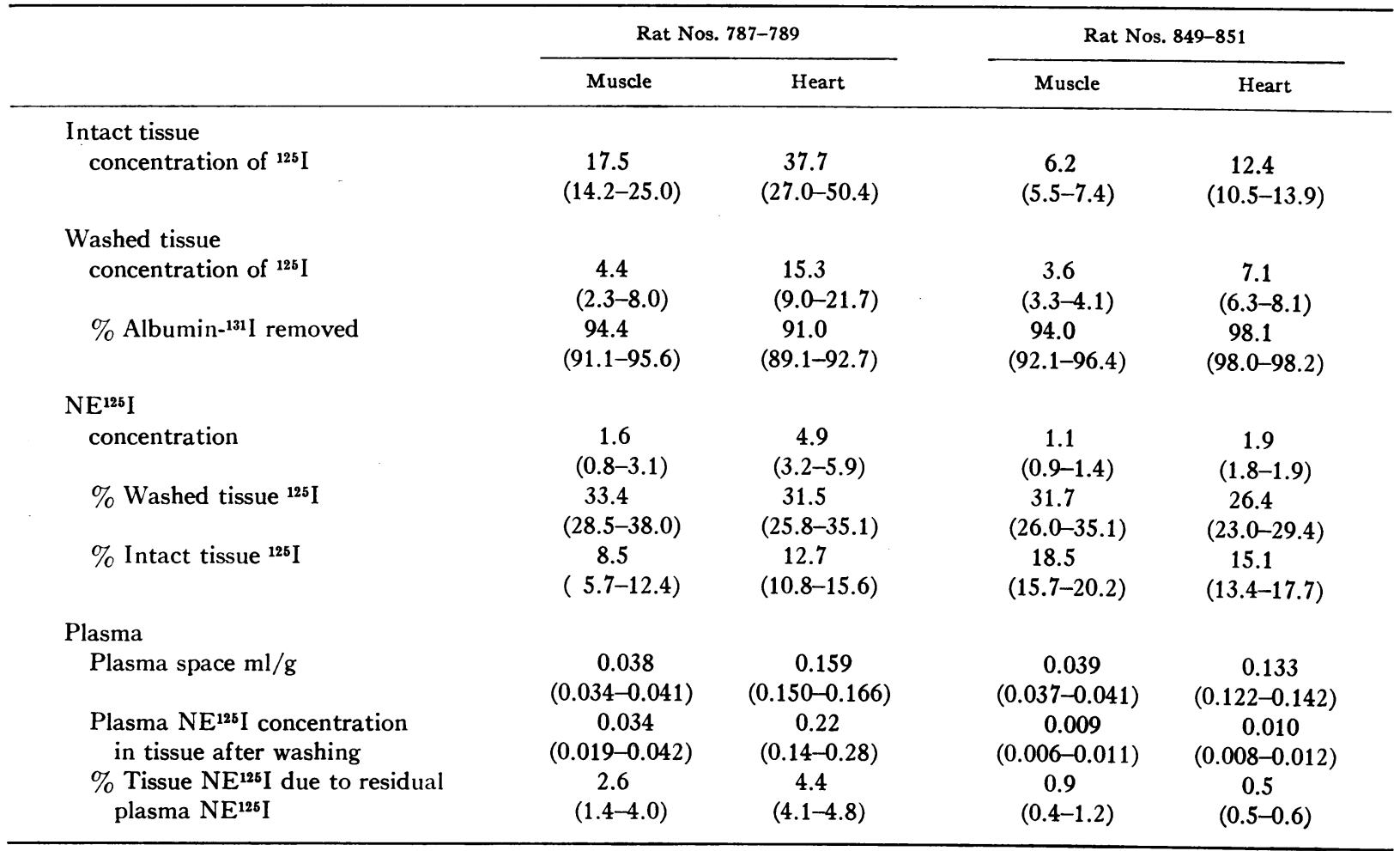

* Data are presented as mean and range for groups of three rats. All concentrations are expressed as $\%$ dose $/ \mathrm{g} \times 10^{4}$. 
TABLE IV

Hepatic Subcellular NE ${ }^{125}$ I after the Metabolism of T3-125I in Control and Phenobarbital (PB)-Treated Rats*

\begin{tabular}{|c|c|c|c|c|c|c|}
\hline \multirow{2}{*}{$\begin{array}{l}\text { Subcellular } \\
\text { fraction }\end{array}$} & \multicolumn{3}{|c|}{ Per cent dose per $g \times 10^{4}$} & \multicolumn{3}{|c|}{ Per cent of total ${ }^{125} I$ in each fraction } \\
\hline & Control & PB-treated & $P<$ & Control & PB-treated & $P<$ \\
\hline Nuclei & $7.9 \pm 0.9$ & $7.5 \pm 0.8$ & NS & $42.7 \pm 2.1$ & $48.7 \pm 1.7$ & 0.05 \\
\hline Mitochondria & $4.6 \pm 0.8$ & $4.4 \pm 0.7$ & NS & $32.6 \pm 3.6$ & $31.4 \pm 3.7$ & NS \\
\hline Microsomes & $12.6 \pm 1.3$ & $26.0 \pm 1.7$ & 0.001 & $48.8 \pm 2.4$ & $64.5 \pm 3.1$ & 0.001 \\
\hline Supernatant & $10.1 \pm 0.7$ & $14.8 \pm 1.0$ & 0.01 & $39.7 \pm 2.6$ & $53.3 \pm 3.3$ & 0.005 \\
\hline
\end{tabular}

* Data are corrected to an ideal body weight of $200 \mathrm{~g}$. Figures represent the mean \pm SEM for groups of 11 rats. Data are pooled from three separate experiments. NS $=$ not significant $(P>0.05)$.

culated. The residual plasma $\mathrm{NE}^{125} \mathrm{I}$ in the tissue after washing was estimated as the product of the plasma $\mathrm{NE}^{125} \mathrm{I}$ concentration, the plasma space per gram of tissue $\left[\left(\%\right.\right.$ dose albumin $-{ }^{131} \mathrm{I} / \mathrm{g}$ tissue $) /(\%$ dose albu$\min -{ }^{131} \mathrm{I} / \mathrm{ml}$ plasma $\left.)\right]$, and the fraction of albumin ${ }^{-131} \mathrm{I}$ remaining in the tissue after washing. These calculations showed that residual plasma $\mathrm{NE}^{125} \mathrm{I}$ contributed only 2.6 and $4.4 \%$ to the observed $\mathrm{NE}^{125} \mathrm{I}$ in the muscle and heart, respectively.

Another study was designed to remove the plasma $\mathrm{NE}^{125} \mathrm{I}$ from the muscle and heart more effectively and to determine whether the $\mathrm{NE}^{125} \mathrm{I}$ in these tissues occurred in the particulate fractions (Table III, rat Nos. 849-851). Homogenates of muscle and heart were obtained from animals injected with $\mathrm{T} 3-{ }^{125} \mathrm{I}$ and albumin${ }^{131} \mathrm{I}$ according to the procedure described above. After washing and extraction of the particulate fractions of these tissue homogenates an average of 18.5 and $15.1 \%$ of the initial muscle and heart ${ }^{125} \mathrm{I}$ was nonextractable. The calculated contribution of residual plasma $\mathrm{NE}^{125} \mathrm{I}$ to the tissue $\mathrm{NE}^{125} \mathrm{I}$ in these studies was less than $1 \%$.

Hepatic subcellular distribution of $N E^{125} I$. The $\mathrm{NE}^{125} \mathrm{I}$ concentration was determined in subcellular fractions prepared from portions of the livers obtained from the same animals described in Tables I and II. Table IV shows the concentration of $\mathrm{NE}^{125} \mathrm{I}$ in the various hepatic subcellular fractions 3 days after the injection of $\mathrm{T} 3{ }^{125} \mathrm{I}$. The highest concentration of $N E^{125} \mathrm{I}$ occurred in the microsomal fraction. The $\mathrm{NE}^{125} \mathrm{I}$ which was observed in the nuclei and mitochondria was not corrected for cross-contamination of these fractions by other organelles. In the PB-treated group, there was a significant increase in the $\mathrm{NE}^{125} \mathrm{I}$ concentration in the microsomes $(P<0.001)$ and in the supernatant fraction $(P<0.01)$. The hepatic subcellular $\mathrm{NE}^{125} \mathrm{I}$ concentrations after $T 4{ }^{125} \mathrm{I}$ metabolism are shown in Table $\mathrm{V}$. The $\mathrm{NE}^{125} \mathrm{I}$ distribution was similar to that obtained after $\mathrm{T}^{2}{ }^{125} \mathrm{I}$ metabolism. Phenobarbital treatment resulted in a marked increase in the microsomal $\mathrm{NE}^{125} \mathrm{I}$ concentration. The small increase in the supernatant fraction was not significant statistically.

In vitro studies. The enzymatic nature of the deiodination of $\mathrm{T} 4$ and $\mathrm{T} 3$ by hepatic microsomes $(12,27,28)$ and the increased rate of deiodination by microsomes from PB-treated rats have been demonstrated previously (20). Fig. 2 demonstrates that a linear relationship was obtained between the reciprocal of the substrate concentration and the reciprocal of the velocity of both iodide formation and NEI formation. Moreover, the rate of formation of NEI and iodide $\left(\mathrm{I}^{-}\right)$was increased when microsomes from PB-treated rats were used. Table VI lists the $\mathrm{V}_{\max }$ for iodide and NEI formation for three experiments using $\mathrm{T} 4$ as substrate and two studies using $\mathrm{T} 3$ as substrate. The increase in $\mathrm{V}_{\max }$ for both reaction products is evident for the $\mathrm{PB}$-treated microsomes. When $\mathrm{M}^{125} \mathrm{IT}$ was incubated with microsomes

TABLE V

Hepatic Subcellular NE ${ }^{125}$ I after the Metabolism of T4-125I in Control and Phenobarbital (PB)-Treated Rats*

\begin{tabular}{|c|c|c|c|c|c|c|}
\hline \multirow{2}{*}{$\begin{array}{l}\text { Subcellular } \\
\text { fraction }\end{array}$} & \multicolumn{3}{|c|}{ Per cent dose per $\mathrm{g} \times 10^{4}$} & \multicolumn{3}{|c|}{ Per cent of total 1251 in each fraction } \\
\hline & Control & PB-treated & $P<$ & Control & PB-treated & $P<$ \\
\hline Nuclei & $11.7 \pm 1.1$ & $11.8 \pm 2.1$ & NS & $60.7 \pm 2.9$ & $64.9 \pm 6.9$ & NS \\
\hline Mitochondria & $6.2 \pm 0.6$ & $6.0 \pm 0.8$ & NS & $46.3 \pm 4.8$ & $46.4 \pm 5.9$ & NS \\
\hline Microsomes & $24.3 \pm 3.7$ & $55.0 \pm 4.8$ & 0.001 & $56.6 \pm 1.9$ & $91.7 \pm 7.6$ & 0.001 \\
\hline Supernatant & $15.3 \pm 2.0$ & $19.9 \pm 4.8$ & NS & $45.1 \pm 2.8$ & $65.6 \pm 4.5$ & 0.005 \\
\hline
\end{tabular}

* Data are corrected to an ideal body weight of $200 \mathrm{~g}$. Figures represent the mean \pm SEM for eight control and six PB-treated rats. Data are pooled from three separate experiments. $\mathrm{NS}=$ not significant $(P>0.05)$. 
from control and PB-treated rats no $\mathrm{NE}^{185} \mathrm{I}$ was formed although substantial deiodination rates for this compound were clearly demonstrated (11.7-57.0\% deiodination per $10 \mathrm{~min}$ in 16 separate incubation flasks). Similarly, no $\mathrm{NE}^{185} \mathrm{I}$ was formed when microsomes were incubated with ${ }^{105} \mathrm{I}^{-}$.

A difference in the hepatic microsomal metabolism of T4 and T3 was observed during all incubation studies. Relative to deiodination, more NEI was formed during T3 metabolism than during T4 metabolism. The mean ratio $\left(\mathrm{V}_{\max } \mathrm{NEI} / \mathrm{V}_{\max } \mathrm{I}^{-}\right)$for the $\mathrm{T} 3$ studies was $0.54 \pm 0.04$ which was significantly greater $(P<0.01)$ than that observed in the T4 studies $0.30 \pm 0.04$ (Table VI).

\section{DISCUSSION}

The present study has demonstrated clearly that NEI occurs in the peripheral tissues as well as in the plasma during the metabolism of the thyroid hormones. Although no chemical characterization of the tissue NEI has been carried out at this time, the nonextractability of hormonal iodine in $95 \%$ ethanol suggests that NEI represents iodoproteins. The highest concentrations of NEI after T3 and T4 metabolism occurred in the liver and kidney. Smaller but nonetheless significant concentra-

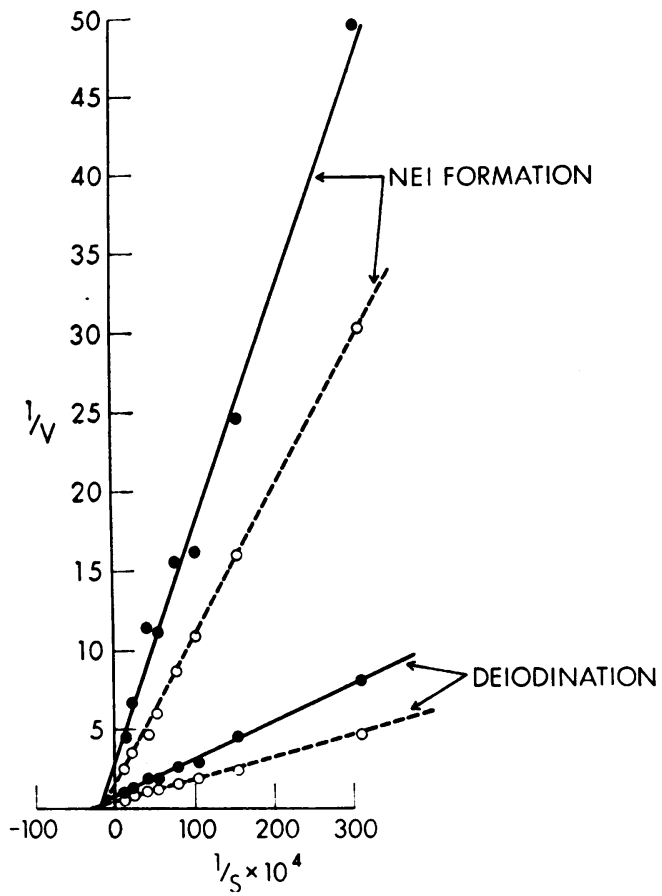

FIgURE 2 Lineweaver-Burk plot of iodide and NEI formation from a representative study of $\mathrm{T} 4$ metabolism by hepatic microsomes harvested from control (-) and PBtreated $\left(\mathrm{O}-\mathrm{O}^{-} \mathrm{O}\right)$ rats. $\mathrm{V}$ is expressed as nanomoles thyroxine converted to iodide or NEI per $10 \mathrm{~min}$ and $\mathrm{S}$ is the molar concentration of thyroxine.
TABLE VI

Effect of Phenobarbital Administration on the Formation of $\mathrm{I}^{-}$ and NEI during the Metabolism of T4 and T3 by Hepatic Microsomes

\begin{tabular}{|c|c|c|c|c|c|c|c|c|c|}
\hline \multirow[b]{4}{*}{ Substrate } & \multirow{4}{*}{$\begin{array}{c}\text { Exp. } \\
\text { No. }\end{array}$} & \multicolumn{6}{|c|}{$\begin{array}{c}\mathrm{V}_{\text {max }}, \mathrm{nmoles} / \mathrm{mg} \text { microsomal protein } \\
\text { per } 10 \mathrm{~min}\end{array}$} & \multirow{3}{*}{\multicolumn{2}{|c|}{$\begin{array}{l}V_{\max } \\
\text { ratio* }\end{array}$}} \\
\hline & & \multicolumn{3}{|c|}{$\mathrm{I}^{-}$} & \multicolumn{3}{|c|}{ NEI } & & \\
\hline & & & & In- & & & & & \\
\hline & & C & PB & crease & $\mathrm{C}$ & PB & crease & $\mathrm{C}$ & $\mathbf{P B}$ \\
\hline & & & & $\%$ & & & $\%$ & & \\
\hline & 1 & 0.43 & 0.83 & 93 & 0.17 & 0.31 & 83 & 0.40 & 0.37 \\
\hline \multirow[t]{2}{*}{ T4 } & 2 & 0.74 & 1.67 & 126 & 0.15 & 0.29 & 93 & 0.20 & 0.17 \\
\hline & 3 & 0.29 & 0.46 & 59 & 0.07 & 0.18 & 157 & 0.24 & 0.39 \\
\hline \multirow[t]{2}{*}{ T3 } & 1 & 0.10 & 0.15 & 50 & 0.05 & 0.09 & 80 & 0.50 & 0.60 \\
\hline & 2 & 0.11 & 0.21 & 91 & 0.07 & 0.09 & 29 & 0.64 & 0.43 \\
\hline
\end{tabular}

Abbreviations: $\mathrm{C}$ refers to microsomes harvested from control rats; $\mathrm{PB}$ refers to microsomes harvested from PB-treated rats.

${ }^{*} V_{\max }$ ratio $=\left(V_{\max } N E I\right) /\left(V_{\max } I^{-}\right)$.

tions of NEI were demonstrated in skeletal and cardiac muscle. The occurrence of NEI in all tissues examined raises the possibility that NEI formation occurs in every tissue which metabolizes the thyroid hormones. The results of our studies may also provide an explanation for the findings of Albert and Keating (29) that in a $300 \mathrm{hr}$ period after the intravenous injection of T4- ${ }^{281}$ I the isotopic tissue/blood ratio of liver, kidney, and carcass progressively increased. This may have represented a proportionately greater accumulation of iodoprotein in tissue than in plasma. No effort was made in these studies to identify the chemical nature of the radioactivity.

The liver fractionation studies indicate that the hepatic NEI is associated with all of the separated subcellular organelles and the soluble fraction. Since the major portion of the hepatic NEI occurred in the microsomal fraction, the NEI which was observed in the nuclear and mitochondrial fractions might be due to the variable contamination of these fractions by microsomes which generally occurs when the current method of differential centrifugation is employed. Further studies utilizing methods which result in highly purified nuclear and mitochondrial fractions and which assess the degree of microsomal contamination of these fractions will be required to determine if NEI does, in fact, occur in the nuclei and mitochondria. The relationship between the hepatic soluble NEI and the circulating iodoproteins demonstrated during thyroid hormone metabolism in this study and previously (1) remains to be elucidated.

A close relationship between the rate of NEI formation and thyroid hormone metabolism in the intact animal is indicated by the increase in NEI concentration in liver and plasma when the rate of hepatic hormone 
metabolism was increased by pretreatment with phenobarbital. Liver fractionation revealed that the increase in hepatic NEI was due primarily to a marked increase in the microsomal fraction. The localization of hepatic NEI to the microsomal fraction and its increase after PB treatment are of special interest. First, subcellular fractionation studies have shown that the microsomal fraction binds a large portion of hepatic T4 after equilibration between liver and plasma has occurred (30). Second, the increase in hepatocellular T4-binding in rats after $\mathrm{PB}$ treatment (31) has been attributed solely to an increase in hepatic microsomal binding (30). Third, in vitro studies of ioclothyronine metabolism by liver microsomes have demonstrated an increase in the specific activity of iodothyronine deiodinase in microsomes harvested from PB-treated rats (20). Finally, the plasma NEI, tentatively identified as iodoalbumin (1), may possibly be synthesized in the hepatic microsomal fraction. The physical proximity of the microsomal sites of iodothyronine metabolism and albumin synthesis and the parallel increases in liver microsomal and plasma NEI in the PB-treated rats thus raise the possibility that iodination of nascent microsomal albumin occurs during the metabolism of the thyroid hormones. Since we have previously estimated that the circulating iodoproteins might be derived entirely from peripheral hormone metabolism (1), it is possible that the elevated plasma iodoprotein concentration in Graves' disease $(32,33)$ may well result from the increased peripheral metabolism of the thyroid hormones in this condition.

The in vitro incubation studies performed in the current investigation show that the kinetics of NEI formation appear to be similar to those of deiodination of the iodothyronines. Furthermore, the increased rate of deiodination by PB-microsomes was accompanied by a proportional increase in the rate of microsomal NEI formation. Other workers have also reported the association of chromatographic origin radioactivity (presumably NEI) and iodide formation during the metabolism of the iodothyronines by liver homogenates $(9,10$, 12) and microsomes (11). The lack of NEI formation during the metabolism of 3 -monoiodotyrosine (MIT) suggests the specificity of this pathway for the iodothyronines. Although the analogy between the in vivo and in vitro studies reported herein is of interest, additional studies must be performed before the in vitro system can be considered a useful model to elucidate the nature of the transfer of hormonal iodine to tissue and plasma proteins. These studies should include a kinetic analysis of the rate of NEI formation in vivo as well as a demonstration of the chemical similarity of the compounds involved.

The commercial preparations of radioactive thyroid hormones used in this investigation were labeled by the iodine exchange reaction which presumably places the radioiodine atom exclusively in the phenolic ring (34). During studies of thyroxine metabolism in vitro, Plaskett (10) and Wynn and Gibbs (11) reported that the major portion of the phenolic ring iodine is removed as iodide. The primary pathway for the nonphenolic ring iodine and the thyronine skeleton, however, was fixation to the structural tissue proteins. The observations in the current report that phenolic ring iodothyronine iodine becomes fixed to tissue proteins in the intact animal thus suggests that other portions of the iodothyronine molecule might be present also. Preliminary studies of the metabolism in rats of nonphenolic ring iodine-labeled $\mathrm{T} 4$ in our laboratory have demonstrated that nonphenolic ring iodothyronine iodine also contributes to plasma and tissue NEI. The potential presence of the carbon thyronine skeleton in these fixed tissue and soluble iodoproteins would be of great interest but must await further investigation.

The available data do not allow any quantitative estimates of the fraction of hormonal iodine which becomes covalently linked to tissue and plasma proteins. Only one arbitrary time interval, after most of the hormone had been metabolized, was examined for each iodothyronine. Moreover, the observed NEI in tissues may represent a number of different iodoproteins each with its own rate of metabolism. The rate of metabolism of plasma NEI, in human subjects, appears similar to that of plasma albumin (1). The data from isotopically equilibrated rats reported previously (1) suggest that, in the steady state, NEI concentration in tissues and plasma constitutes approximately $10 \%$ of the organic iodine. Even if only a small fraction of hormonal iodine becomes linked to structural tissue and soluble proteins, the chemical alteration of these cellular constituents during hormonal metabolism may be of basic physiological importance.

\section{ACKNOWLEDGMENTS}

We are indebted to $\mathrm{Mr}$. Modesto Martinez, Mr. Frank Martinez, Mr. Jose Guerra, and Mrs. Barbara Hickey for expert technical support and to Miss Joan Tomes and Mrs. Marian Zullo for secretarial assistance.

This work was supported by U. S. Army Contract DA-49193-MD-2967 and U. S. Public Health Service Grant NB-03000.

\section{REFERENCES}

1. Surks, M. I., and J. H. Oppenheimer. 1969. Formation of iodoprotein during the peripheral metabolism of $3,5,3^{\prime}$ triiodo-L-thyronine- ${ }^{255} \mathrm{I}$ in the euthyroid man and rat. J. Clin. Invest. 48: 685.

2. Brown-Grant, K. 1967. Further studies of the metabolism of thyroxine and 3,5,3'-triiodothyronine in the guinea pig. J. Physiol. 191 : 167.

3. Tata, J. R. 1960. Transiodination of proteins during enzymic de-iodination of thyroxine. Nature (London). 187: 1025 . 
4. Tata, J. R. 1960. The partial purification and properties of thyroxine dehalogenase. Biochcm. J. 77: 214.

5. Tata, J. R. 1962. Intracellular and extracellular mechanisms for the utilization and action of thyroid hormones. Recent Progr. Hormone Res. 18: 221.

6. Jacquemin, C., J. Nunez, and J. Roche. 1963. Sur les produits intermédiaires et le méchanisme de la désiodation des hormones thyroïdiennes. Gen. Comp. Endocrinol. 3: 226.

7. Lissitzky, S., M. Roques and M.-T. Benevent. 1961. Désiodation enzymatique de la thyroxine et de ses dérivés. I. Purification et propriétés de la thyroxinedésiodase de muscle de lapin. Bull. Soc. Chim. Biol. 43: 727.

8. Lissitzky, S., M.-T. Benevent, and M. Roques. 1961. Désiodation enzymatique de la thyroxine et de ses dérivés. II. Produits formés et mécanisme de la réaction. Bull. Soc. Chim. Biol. 43: 743.

9. Galton, V. A., and S. H. Ingbar. 1961. The mechanism of protein iodination during the metabolism of thyroid hormones by peripheral tissues. Endocrinology. 69: 30 .

10. Plaskett, L. G. 1961. Studies on the degradation of thyroid hormones in vitro with compounds labeled in either ring. Biochem. J. 78: 652 .

11. Wynn, J., and R. Gibbs. 1962. Thyroxine degradation. II. Products of thyroxine degradation by rat liver microsomes. J. Biol. Chem. 237: 3499.

12. Nakagawa, S., and W. R. Ruegamer. 1967. Properties of a rat tissue iodothyronine deiodinase and its natural inhibitor. Biochemistry. 6: 1249.

13. Galton, V. A., and S. H. Ingbar. 1962. A photoactivated flavin-induced degradation of thyroxine and related phenols. Endocrinology. 70: 210.

14. Reinwein, D., and J. E. Rall. 1966. Nonenzymatic deiodination of thyroid hormones by flavin mononucleotide and light. J. Biol. Chem. 241: 1636.

15. Morreale de Escobar, G., P. L. Rodriquez, T. Jolin, and F. Escobar del Rey. 1963. Activation of the flavin photodeiodination of thyroxine by "thyroxine deiodinase" and other proteins. J. Biol. Chem. 238: 3508.

16. Ford, D. H., K. R. Corey, and J. Gross. 1957. The localization of thyroid hormones in the organs and tissues of the guinea pig: an autoradiographic and chromatographic study. Endocrinology. 61: 426.

17. Nunez, J., L. Rappaport, C. Jaquemin, and J. Roche. 1964. Désiodation in vivo de ${ }^{3} \mathrm{H}$ - et $3,5{ }^{185} \mathrm{I}$-thyroxine. $C$. $R$. Soc. Biol. Paris. 158: 12.

18. Dratman, M. B., H. Kuhlenbeck, and F. Crutchfield 1968. Fate of thyroxine in the neuraxis of the newborn rat. Anat. Rec. 160: 341. (Abstr.)

19. Oppenheimer, J. H., G. Bernstein, and M. I. Surks. 1968. Increased thyroxine turnover and thyroidal func- tion after stimulation of hepatocellular binding of thyroxine by phenobarbital. J. Clin. Invest. 47: 1399.

20. Schwartz, H. L., V. Kozyreff, M. I. Surks, and J. H. Oppenheimer. 1969. Increased deiodination of L-thyroxine and L-triiodothyronine by liver microsomes from phenobarbital-treated rats. Nature (London). 221: 1262.

21. Greenwood, F. C., W. M. Hunter, and J. S. Glover. 1963. The preparation of ${ }^{131}$ I-labeled human growth hormone of high specific radioactivity. Biochem. J. 89: 114.

22. Schneider, W. C., and G. H. Hogeboom. 1950. Intracellular distribution of enzymes. VI. The distribution of succinoxidase and cytochrome oxidase activities in normal mouse liver and in mouse hepatoma. J. Nat. Cancer Inst. 10: 969 .

23. Johnson, P. O. 1949. Statistical Methods in Research. New York, Prentice-Hall Inc., Englewood Cliffs, N. J.

24. Berson, S. A., and R. S. Yalow. 1957. Radiochemical and radiobiological alterations of $\mathrm{I}^{181}$-labeled proteins in solution. Ann. N. Y. Acad. Sci. 70: 56.

25. Stanbury, J. B. 1957. The requirement of monoiodotyrosine deiodinase for triphosphopyridine nucleotide. J. Biol. Chem. 228: 801 .

26. Lineweaver, H., and D. Burk. 1934. Determination of enzyme dissociation constants. J. Amer. Chem. Soc. 56: 658.

27. Stanbury, J. B., M. L. Morris, H. J. Corrigan, and W. L. Lassiter. 1960. Thyroxine deiodination by a microsomal preparation requiring $\mathrm{Fe}^{++}$, oxygen, and cysteine or glutathione. Endocrinology. 67: 353 .

28. Wynn, J., R. Gibbs, and B. Royster. 1962. Thyroxine degradation. I. Study of optimal reaction conditions of a rat liver thyroxine-degrading system. J. Biol. Chem. $237: 1892$

29. Albert, A., and F. Raymond Keating, Jr. 1952. The role of the gastrointestinal tract including the liver in the metabolism of radiothyroxine. Endocrinology. 51: 427.

30. Schwartz, H. L., G. Bernstein, and J. H. Oppenheimer. 1969. Effect of phenobarbital administration on the subcellular distribution of ${ }^{125} \mathrm{I}$-thyroxine in rat liver: importance of microsomal binding. Endocrinology. 84: 270.

31. Bernstein, G., J. Hasen, S. A. Artz, and J. H. Oppenheimer. 1968. Hepatic accumulation of ${ }^{125} \mathrm{I}$-thyroxine in the rat: augmentation by phenobarbital and chlordane. Endocrinology. 82: 406.

32. Cameron, C., and K. Fletcher. 1959. An iodine compound associated with albumin in the plasma of thyrotoxic patients. Nature (London). 183: 116

33. Stanbury, J. B., and M. A. Janssen. 1962. The iodinated albumin-like component of the plasma of thyrotoxic patients. J. Clin. Endocrinol. 22: 978.

34. Gleason, G. I. 1955. Some notes on the exchange of iodine with thyroxine homologues. J. Biol. Chem. 213: 837. 